\title{
Article
}

\author{
Doi 10.5943/sif/6/1/10
}

\section{Cyathus striatus: a new record from Arunachal Pradesh and a checklist of Bird's nest fungi in India}

\section{Niranjan $M^{*}$ and Singh RK}

Department of Botany, Rajiv Gandhi University, Rono Hills, Doimukh, Arunachal Pradesh 791112, India

Niranjan M, Singh RK 2021 - Cyathus striatus: a new record from Arunachal Pradesh and a checklist of Bird's nest fungi in India. Studies in Fungi 6(1), 168-174, Doi 10.5943/sif/6/1/10

\begin{abstract}
Twenty four species of Bird's nest fungi belonging to four genera, namely Crucibulum, Cyathus, Nidula and Sphaerobolus have been reported from India with most of the reports were from Northeastern states in the Eastern Himalaya region that is well recognized for its rich biodiversity. Among these genera, Cyathus is the largest genus with 61 species documented so far in the world including 17 species from India. So far, only Cyathus poeppigii has been reported from the Eastern Himalayan state of Arunachal Pradesh. In the present paper, another newly recorded species Cyathus striatus, is reported with its detail taxonomic characteristics. It produces comparatively smaller basidiocarps than the earlier reported collection from Darjeeling (West Bengal). Further, the basidiospores are thin walled but comparatively larger in size. The paper also lists all Bird's nest fungi from India with detailed information.
\end{abstract}

Key words - Agaricomycetes - Checklist - Cyathus - Eastern Himalaya

\section{Introduction}

The tropical and subtropical forests harbor a great fungal diversity and with integrative taxonomic approach many new taxa have been reported (Accioly et al. 2018). Basidiomycota, which is the second largest phylum after Ascomycota in the Fungal kingdom, has recently been revised in detailed notes and outline (He et al. 2019, Wijayawardene et al. 2020).

One of most beautiful group of Basdiomycota is Bird's nest fungi which are distributed in six genera, namely Crucibulum, Cyathus, Mycocalia, Nidula, Nidularia and Sphaerobolus (Zhou et al. 2004, Poinar 2014, Cruz \& Baseia 2014, Geml et al. 2015, Sharma 2016, Cruz 2017, He et al. 2019). These fungi do not have anamorphic state (Shinners et al. 1997) and were earlier placed in the family Nidulariaceae but have been presently transferred to the family Agaricaceae (Das \& Zhao 2013). Except Sphaerobolus, other genera of this group that produce multiple peridioles have been placed in incertae sedis under the order Agaricales, Agaricomycetes (He et al. 2019). Taxonomic key of Bird's nest fungi has been published by Das \& Zhao (2013).

Crucibulum Tul. \& C. Tul. (1844) is characterized by interior smooth and tawny yellow cup, simple funiculus and white peridioles. Seven species of Crucibulum have been recorded in the world viz. C. albosaccum, C. crucibuliforme, $C$. cyathiforme, C. laeve, C. parvulum, $C$. simile and $C$. vulgare. From India, only two species $C$. laeve and $C$. vulgare have been so far reported.

Genus Cyathus Haller (1768) is saprobic, grows on decaying wood and fertile soil, forming gregarious basidiomata, either cone, funnel or inverted bell shaped, up to $3 \mathrm{~cm}$ in height, and contains more than one peridiole, gray to black in colour, connected to a three layered peridium 
with a funicular cord (Dorjey et al. 2013). It is the largest genus of Bird's nest fungi with 61 recorded species (Accioly et al. 2018, He et al. 2019, Góis et al. 2020) with a maximum number reported from Brazil. The world revision of Cyathus has been published by Cruz (2017). According the Queensland Mycological Society key to Bird's nest Fungi, both Crucibulum and Cyathus have funicular cord whereas Mycocalia, Nidula and Nidularia do not. Recent phylogenetic analysis placed Cyathus closer to Cystoderma of the family incertae sedis, Agaricales (Wijayawardene et al. 2020).

Mycocalia J.T. Palmer (1961) is a distinct genus of Bird's nest fungi having globose to subglobose basidiomata, hyaline to brown peridium, peridioles in hyaline gelatinous matrix, and cylindrical to ellipsoid, hyaline basidiospores. Currently, 7 species of Mycocalia have been recorded viz. $M$. aquaphila, $M$. arundinacea, $M$. denudate, M. duriaeana, M. minutissima, $M$. reticulata and $M$. sphagneti (Index Fungorum 2021).

Nidula V.S. White (1902) consists of 7 species (Das \& Zhao 2013, Poinar 2014), morphologically characterized by urn- to vase-shaped basidiomata containing lenticular brown peridioles, peridium 6-layered, mouth covered by a lid, tunica layer around the peridioles, basidiospores broadly ellipsoid to elongate, hyaline and smooth walled. Three species of this genus have been recorded from India viz. Nidula candida, N. emodensis and N. shingbaensis.

Nidularia Fr. (1817), is the type genus of the family Nidulariaceae. It is characterized by a soft, early deliquescent, pulverulent basidiomata surface, and peridium composed of spinose hyphae (Baseia \& Milanez 2001). Like Mycocalia, Nidularia also lack epiphragm. Three species have so far been reported viz. $N$. confluens, $N$. farcta and $N$. pulvinata but none from India.

Sphaerobolus, described by Tode (1790), is a unique genus with a minute basidiomata containing single brown peridiole. Due to a distinct spore-dispersal mechanism, it is popularly called artillery fungus. Under this genus (currently placed under Geastraceae, Geastrales, Agaricomycetes; He et al. 2019), four species, namely S. iowensis, S. ingoldii, S. stellatus and S. jaysukhianus are accepted, out of which later two species are reported from India (Vasava et al. 2020).

In India, 17 Bird's nest fungi distributed in three genera have been enlisted by Das \& Zhao (2012) including 1 species of Crucibulum, 14 species of Cyathus and 2 species of Nidula. Thereafter, many species were added (Table 1) to these three genera and two more species to Sphaerobolus viz. S. jaysukhianus and S. stellatus (Das \& Zhao 2013, Vasava et al. 2020).

Table 1 Checklist of Bird's nest fungi of India

\begin{tabular}{|l|l|l|l|}
\hline Name of the species & Substratum & Site & Reference \\
\hline $\begin{array}{l}\text { Crucibulum laeve* } \\
\text { (Huds.) Kambly 1936. }\end{array}$ & Unknown & Unknown & Das \& Zhao (2012) \\
\hline $\begin{array}{l}\text { C. vulgare Tul. \& C. Tul. } \\
1844 .\end{array}$ & Unknown & Nilgiris (Tamila Nadu) & $\begin{array}{l}\text { Butler \& Bisby } \\
\text { (1931) }\end{array}$ \\
\hline $\begin{array}{l}\text { Cyathus. Colensoi* Berk. } \\
1855 .\end{array}$ & $\begin{array}{l}\text { Dead twigs and } \\
\text { soil }\end{array}$ & $\begin{array}{l}\text { Shimla hills (Himachal Pradesh), } \\
\text { Siliguri (West Bengal), Phey village } \\
\text { (Leh, Ladakh) }\end{array}$ & $\begin{array}{l}\text { Yangdol et al. } \\
(2018)\end{array}$ \\
\hline $\begin{array}{l}\text { C. } \text { ellipsoideus H.J. Brodie } \\
\text { 1974. }\end{array}$ & Unknown & Chikmaglur (Karnataka) & Sharma (2016) \\
\hline $\begin{array}{l}\text { C. gracilis* H.J. Brodie } \\
\text { 1973. }\end{array}$ & Twigs & Sevoke (Siliguri, West Bengal) & Sharma (2016) \\
\hline $\begin{array}{l}\text { C. griseocarpus* Brodie \& } \\
\text { B.M. Sharma 1980. }\end{array}$ & $\begin{array}{l}\text { Dead twigs and } \\
\text { soil }\end{array}$ & Ukhrul (Manipur) & $\begin{array}{l}\text { Brodie \& Sharma } \\
\text { (1980) }\end{array}$ \\
\hline $\begin{array}{l}\text { C. hookeri* Berk. 1854. } \\
\text { Unknown }\end{array}$ & $\begin{array}{l}\text { Kollong rock (Khashia hills, } \\
\text { Meghalaya) }\end{array}$ & Sharma (2016) \\
\hline $\begin{array}{l}\text { C. } \text { intermedius* Tul. \& C. } \\
\text { Tul. } 1844 .\end{array}$ & Unknown & $\begin{array}{l}\text { Sibpur (near Calcutta, West Bengal), } \\
\text { Manali (Himachal Pradesh) }\end{array}$ & Sharma (2016) \\
\hline
\end{tabular}


Table 1 Continued.

\begin{tabular}{|c|c|c|c|}
\hline Name of the species & Substratum & Site & Reference \\
\hline $\begin{array}{l}\text { C. limbatus* Tul. \& C. Tul. } \\
\text { 1844. }\end{array}$ & Dead wood & Nongpoh (Khasi hills, Meghalaya) & Góis et al. (2020) \\
\hline $\begin{array}{l}\text { C. microsporus Tul. \& C. } \\
\text { Tul. } 1844 .\end{array}$ & Unknown & Khasi hills (Meghalaya) & Sharma (2016) \\
\hline $\begin{array}{l}\text { C. novae-zelandiae } \\
\text { Tul. \& C. Tul. } 1844 .\end{array}$ & $\begin{array}{l}\text { Dead wooden } \\
\log \end{array}$ & Jatinga (Haflong, N.C. Hills, Assam) & Sharma (2016) \\
\hline C. olla* (Batsch) Pers. 1801. & Unknown & Ladakh & $\begin{array}{l}\text { Dorjey et al. } \\
\text { (2013) }\end{array}$ \\
\hline $\begin{array}{l}\text { C. poeppigii* Tul. \& C. Tul. } \\
1844 .\end{array}$ & Soil and twigs & $\begin{array}{l}\text { Bomdila \& Nichifu (West Kameng, } \\
\text { Arunachal Pradesh) }\end{array}$ & $\begin{array}{l}\text { Das \& Zhao } \\
(2012)\end{array}$ \\
\hline $\begin{array}{l}\text { C. renweii* T.X. Zhou \& } \\
\text { R.L. Zhao } 2004 .\end{array}$ & Unknown & Basgo (Leh, Ladakh) & $\begin{array}{l}\text { Yangdol et al. } \\
(2018)\end{array}$ \\
\hline $\begin{array}{l}\text { C. stercoreus* (Schwein.) } \\
\text { De Toni } 1888 .\end{array}$ & $\begin{array}{l}\text { Soil and wild } \\
\text { animal dung }\end{array}$ & $\begin{array}{l}\text { Khasi hills (Meghalaya), } \\
\text { Shoolpaneshwar Wildlife Sanctuary } \\
\text { (Sagai, Gujarat) }\end{array}$ & Patel et al. (2018) \\
\hline $\begin{array}{l}\text { C. striatus* (Huds.) Willd. } \\
1787 .\end{array}$ & Soil and twigs & $\begin{array}{l}\text { Darjeelin, (West Bengal) Emchi } \\
\text { (Papum Pare, Arunachal Pradesh) }\end{array}$ & This study \\
\hline $\begin{array}{l}\text { C. thindii K. Das, Hembrom, } \\
\text { A. Parihar \& R.L. Zhao } \\
2015 .\end{array}$ & Unknown & $\begin{array}{l}\text { A.J.C Bose College (Howrah, West } \\
\text { Bengal) }\end{array}$ & Cruz (2017) \\
\hline C. triplex* Lloyd 1906. & Soil and twigs & Baramulah (Agartala, Tripura) & Sharma (2016) \\
\hline $\begin{array}{l}\text { C. montagnei* Tul. \& C. } \\
\text { Tul. } 1844 .\end{array}$ & Unknown & Dehradun (Uttarakhand) & Sharma (2016) \\
\hline Nidula candida* Peck 1893. & $\begin{array}{l}\text { Dead twigs of } \\
\text { Abies densa }\end{array}$ & Between Hilley and Barsey (Sikkim) & $\begin{array}{l}\text { Das \& Zhao } \\
(2012)\end{array}$ \\
\hline $\begin{array}{l}\text { N. emodensis (Berk.) } \\
\text { Lloyd } 1906 .\end{array}$ & Dead wood & Lachen (Sikkim) & $\begin{array}{l}\text { Butler \& Bisby } \\
\text { (1931) }\end{array}$ \\
\hline $\begin{array}{l}\text { N. shingbaensis* K. Das \& } \\
\text { R.L. Zhao } 2013 .\end{array}$ & $\begin{array}{l}\text { Dead twigs of } \\
\text { Abies densa }\end{array}$ & $\begin{array}{l}\text { Shingba Rhododendron Sanctuary, } \\
\text { (North District, Sikkim) }\end{array}$ & Das \& Zhao (2013) \\
\hline $\begin{array}{l}\text { Sphaerobolus } \\
\text { jaysukhianus* AM Vasava, } \\
\text { RS Patel \& KS Rajput 2020. }\end{array}$ & Cow dung & Ajwa Road (Vadodara, Gujarat) & Vasava et al. (2020) \\
\hline S. stellatus* Tode 1790. & Dead moss & $\begin{array}{l}\text { Botanic garden (Saharanpur, Uttar } \\
\text { Pradesh) }\end{array}$ & $\begin{array}{l}\text { Butler \& Bisby } \\
\text { (1931) }\end{array}$ \\
\hline
\end{tabular}

Note: Bold letters indicate new species, ${ }^{*}$ Indicates molecular data available, Name of the province (State) of India has been put within bracket.

\section{Material \& methods}

Fresh basidiomata growing on dead and decaying wood were collected from the Doimukh, Papum Pare district, Arunachal Pradesh, and the macro-morphological characters were noted. Its surface was cleaned with $70 \%$ ethyl alcohol before microscopic examination. The samples were examined under stereo zoom microscope (Zeiss Stemi 508, Germany) to locate the structures and photographed with attached Axiocam ERc 5s digital camera. Free-hand sections of basidiomata was prepared and mounted in lactophenol-cotton blue solution. Detailed microscopic examination of fungal structures and microphotography was done under Zeiss Axio Lab. A1 microscope equipped with Axiocam Erc 5s digital camera. Size measurements were taken by ZEN-2012 imaging software version 8.0.0. Photographic plates were prepared using Adobe Photoshop version 7.0. Morphological identification was performed by referring to the outline and notes for Basidiomycota (He et al. 2019, Wijayawardene et al. 2020). Herbarium samples were deposited in the fungal herbaria of the department. Facesoffungi number was registered as described in Jayasiri et al. (2015). 


\section{Taxonomy}

Cyathus striatus (Huds.) Willd. 1787

Index Fungorum number: IF211223; Facesoffungi number: FoF09811

Fig. 1

Saprobic on decaying wood. Teleomorph: Basidiomata 6-8 $\times 5-6 \mathrm{~mm}$ diameter at mouth, narrowing towards base, short stalk, scattered to gregarious, infundibuliform with hyaline puffy, basal brown to dark brown apical ends. Epiphragm hyaline and rupturing at maturity. Stipe attached to wood, cross section revealing three layers, outer one bearing pale brown hair like structures, Exoperidium consisting of wooly trimitic hyphae in which generative hyphae hyaline with or without clamp connections, frequently septate and branched; binding hyphae 2.6-3.3 $\mu \mathrm{m}$ wide, hyaline to pale brown, distantly septate with clamp connections; skeletal hyphae $2.5-3.2 \mu \mathrm{m}$, thick walled, brown without septa and rarely branched. Peridium $>164.5 \mu \mathrm{m}$ and in the middle $>153.8$ $\mu \mathrm{m}$ thick, consisting of three different layers. Outer wall conspicuously plicate, tomentose, arranged in regular flexible tufts or fibrose hyaline to pale brown hyphae, 4.7-5.8 $\mu \mathrm{m}$ wide, rarely branched, apical cells ovoid with apiculate ends, middle wall hyaline to pale brown, tightly packed textura intricata hyphae, $2.6-2.8 \mu \mathrm{m}$, highly branched, inner wall gray to brown textura, epidermoid tissue. Peridioles $1-1.3 \times 0.2-0.3 \mathrm{~mm}, 10-12$ per basidioma, circular to elliptical, surface smooth to wrinkled, sticky in nature, coated with thin mucilaginous gel when moist. Funiculus present, Funiculi 3.8-5.1 $\mu \mathrm{m}$, pale yellowish in colour, composed of mycelial cords branching but without septa. Peridiole three layered, covered with thin tunica $>15.5 \mu \mathrm{m}$ thick; Exocortex brown to black, 7.8-12.0 $\mu \mathrm{m}$, endocortex 40-142 $\mu \mathrm{m}$ wide and hyaline, hymenium 81-86 $\mu \mathrm{m}$ wide consisting of branched hyphae 1.1-2.5 $\mu \mathrm{m}$ wide. Basidiospores $13.5-19.0 \times 9.6-12.0(13.4) \mu \mathrm{m}(\bar{x}=16.4 \times$ 10.8, $\mathrm{n}=25)$, ellipsoid, thick and smooth walled $(2.4-3.3 \mu \mathrm{m})$, apiculated sometimes, hyaline when immature, becoming sub-hyaline at maturity and become smaller, borne on irregularly scattered basidia in hymenium. Anamorph undermined.

Known distribution - Throughout the world.

Material examined - INDIA, Arunachal Pradesh, Papum Pare, Doimukh, 2708'22.1"N 93 46'07.1"E on 18 September, 2020, on decaying wood, collected by Naniya Takha, identified by Niranjan. M. Specimen voucher number: ARFR-151, deposited in Department of Botany, Rajiv Gandhi University, Arunachal Pradesh.

Notes - Das \& Zhao (2012) provided the key to Indian Cyathus species that are mainly differentiated by the number of peridial layers. Present specimen contained three layered peridium, peridiole covered with tunica, basidiospores longer than $15 \mu \mathrm{m}$, and is similar to C. ellipsoideus, $C$. intermedius and $C$. striatus. Further, based on morphological characters, the collected specimens shared similar Basidial and Peridial characters with $C$. striatus. However, in comparison to the previous report (Sharma 2016), the basidiospores of the specimen of $C$. striatus in our collection were slightly larger $(13.5-19.0 \times 9.6-12.0(13.4)$ vs. $11-18 \times 9-12 \mu \mathrm{m})$ but with thinner wall $(2.4$ 3.3 vs. $\sim 3.5 \mu \mathrm{m})$. Therefore, the key morphological characters do ensure that it fits into $C$. striatus, and this species has been recorded for the first time in Arunachal Pradesh.

\section{Discussion}

Twenty four species of Bird's nest fungi belonging to four genera have been recorded so far from India (Crucibulum: 2 species, Cyathus: 17 species, Nidula: 3 species, and Sphaerobolus: 2 species). Crucibulum has been reported from the state of Tamil Nadu whereas Sphaerobolus from Gujarat and Uttar Pradesh. The highest number of species of Cyathus has been recorded in India with several species found in Northeastern region of the country that lies within the Eastern Himalayas. C. striatus was reported for the first time in Northeastern region from Darjeeling (West Bengal) and second time in the present study from the state of Arunachal Pradesh. Nevertheless, the specimens in our collection are with comparatively smaller Basidioma containing slightly larger but thin walled basidiospores in comparison to the said previous record. Three species of Nidula have been recorded, all from the state of Sikkim in the Eastern Himalayas, thus reflecting its narrow geographical distribution in India. 

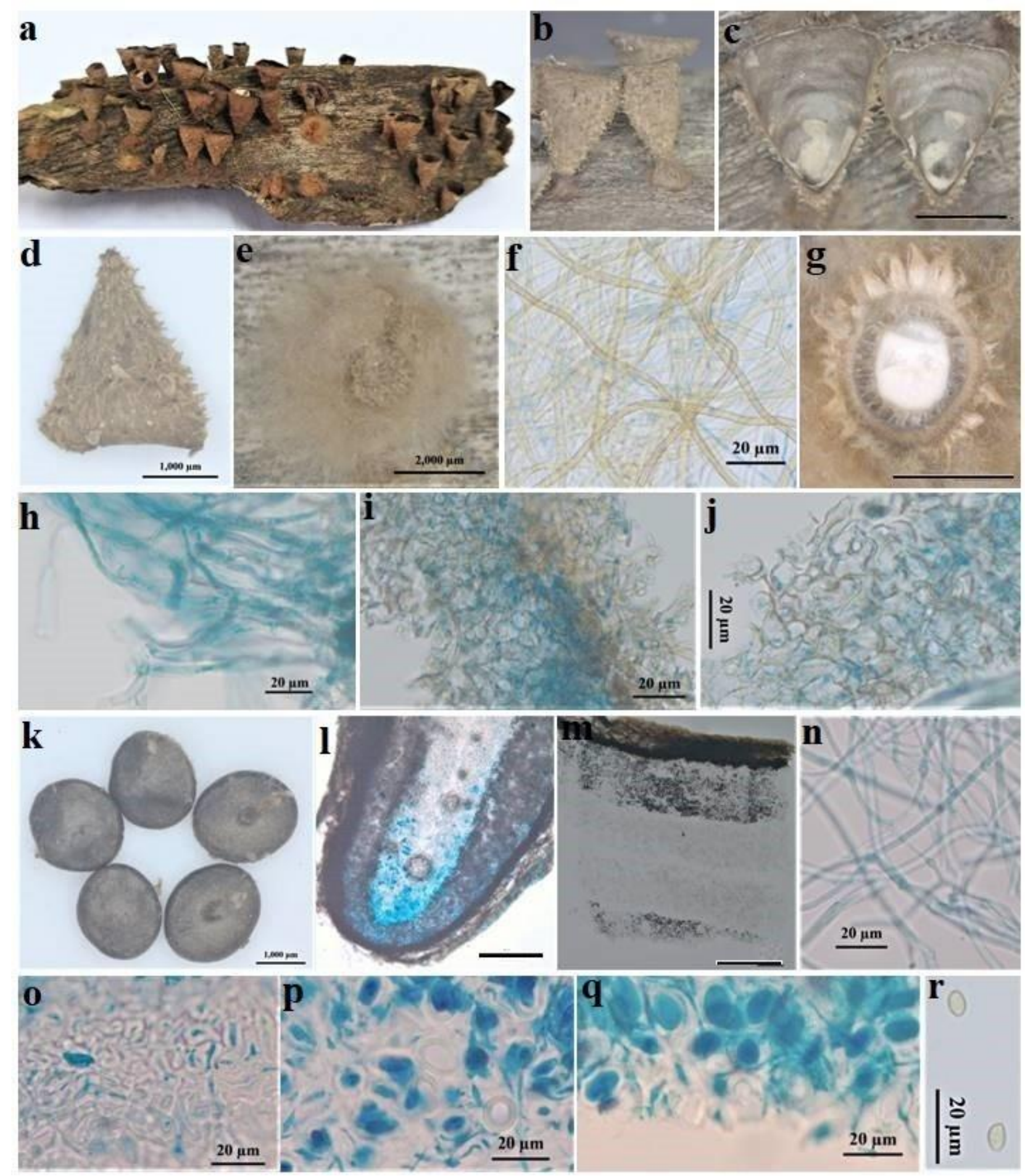

Fig. 1 - Cyathus striatus (ARFR-151). a, b Basidiomata. c Endoperidium. d Exoperidium. e Immature basidia. f Stipe associated hyphae. g Stipe section. h-j Peridial layers. k Peridioles with funiculi. 1, $\mathrm{m}$ Cross section of peridiole. $\mathrm{n}$ Funiculus hyphae. o Sub-cortex section of peridiole. p-q Basidiospores. $r$ Basidiospores. Scale bar: c, $g=3000 \mu \mathrm{m}, \mathrm{d}-\mathrm{e}=2000 \mu \mathrm{m}, 1-\mathrm{m}=40 \mu \mathrm{m}$.

\section{Acknowledgements}

First author thanks Department of Biotechnology (DBT), Govt. of India for providing Research Associateship. We acknowledge financial support received from DBT (Research Project No. BT/PR25530/NER/95/1239/2017) and the infrastructural support provided under UGC-CPEB, DST-FIST schemes and DBT e-Library Consortium of Govt. of India. We thank Department of Botany, Rajiv Gandhi University for providing research facilities. 


\section{References}

Accioly T, Cruz RH, Assis NM, Ishikawa NK et al. 2018 - Amazonian Bird's nest fungi (Basidiomycota): Current knowledge and novelties on Cyathus species. Mycoscience 59, 331-342.

Baseia IG, Milanez AI. 2001 - Nidularia pulvinata (Schwein.) Fries (Gasteromycetes): a new record from Brazil. Brazilian Journal of Botany 24, 479-481.

Brodie HJ, Sharma BM. 1980 - Cyathus griseocarpus a new Bird's nest fungus from India. Botaniska Notiser 133, 343-345.

Butler EJ, Bisby GR. 1931 - The Fungi of India. Imperial Council of Agriculture Research, Indian Science Monograph. I 18, 237

Cruz RH. 2017 - Morphological and Molecular Review of the Cyathus Haller Genus (Nidulariaceae, Agaricales, Basidiomycota), Doctoral thesis.

Cruz RH, Baseia I. 2014 - Four new Cyathus species (Nidulariaceae, Basidiomycota, Fungi) from the semi-arid region of Brazil. Journal of the Torrey Botanical Society 141, 173-180.

Das K, Zhao R. 2012 - Bird's Nest fungi in India: a new record from Sikkim. Biodiversity and Taxonomy 61-68.

Das K, Zhao RL. 2013 - Nidula shingbaensis sp. nov., a new Bird's nest fungus from India. Mycotaxon 125, 53-58.

Dorjey K, Kumar S, Sharma YP. 2013 - Cyathus olla from the cold desert of Ladakh. Mycosphere 4, 256-259.

Geml J, Davis DD, Geiser DM. 2005 - Systematics of the genus Sphaerobolus based on molecular and morphological data, with the description of Sphaerobolus ingoldii sp. nov. Mycologia 97, 680-694.

Góis JS, da Cruz RH, Nascimento PH, Baseia IG. 2020 - A new species and new records of Cyathus (Agaricales, Basidiomycota) from a National Park in Bahia, Brazil. New Zealand Journal of Botany 12, 1-12.

Haller AV. 1768 - Historia stirpium indigenarum Helvetiae inchoate. Sumptibus Societatis Typographicae 3, 236.

He MQ, Zhao RL, Hyde KD, Begerow D et al. 2019 - Notes, outline and divergence times of Basidiomycota. Fungal diversity 99, 105-367.

Index Fungorum. 2021 - http://www.indexfungorum.org/names/ names.asp. (Accessed on February 28, 2021).

Jayasiri SC, Hyde KD, Ariyawansa HA, Bhat J et al. 2015 - The Faces of Fungi database: fungal names linked with morphology, phylogeny and human impacts. Fungal Diversity 74, 3-18. Doi 10.1007/s13225-015-0351-8

Palmer JT. 1961 - Observations on Gasteromycetes IX. The conservation of Nidularia Fr. and the separation of Mycocalia J.T. Palmer, gen nov. Taxon 10, 54-60.

Patel RS, Vasava AM, Rajput KS. 2018 - New distribution record of Cyathus stercoreus (Schwein.) De Toni (Nidulariaceae) for India from Gujarat state. Studies in Fungi 3, 227-233.

Poinar Jr G. 2014 - Bird's nest fungi (Nidulariales: Nidulariaceae) in baltic and dominican amber. Fungal biology 118, 325-329.

Sharma BM. 2016 - Genus Cyathus Haller exPers. (Agaricomycetes) from Eastern Himalaya. Kavaka 47, 20-26.

Shinners TC, Tewari JP. 1997 - Diversity in crystal production by some Bird's nest fungi (Nidulariaceae) in culture. Canadian journal of chemistry 75, 850-856.

Tode HJ. 1790 - Sphaerobolus stellatus. Fungi Mecklenburgenses selecti (Luneburgi) 1, 43.

Vasava AM, Patel RS, Rajput KS. 2020 - Sphaerobolus jaysukhianus sp. nov. An artillery fungus (Geastraceae, Basidiomycota) from India. Plant Biosystems - An International Journal Dealing with all Aspects of Plant Biology, Pp. 1-8.

Wijayawardene NN, Hyde KD, Al-Ani LK, Tedersoo L et al. 2020 - Outline of Fungi and funguslike taxa. Mycosphere 11, 1060-1456. 
Yangdol R, Kumar S, Sharma YP. 2018 - Two more Bird's nest fungi from cold desert of Ladakh, India. Studies in Fungi 3, 79-83.

Zhou TX, Zhao LZ, Zhao RL, Chen YH. 2004 - Bird's nest fungi from China. Fungal Diversity 17, 243-251. 